\title{
WACSeries
}

Volume 7, Issue 6 - April 2021

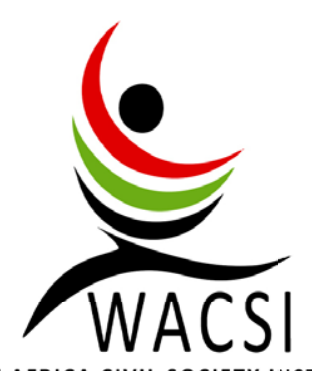

WEST AFRICA CIVIL SOCIETY INSTITUTE

\section{Assessing the Influence of the Media on the Work of Development Organisations}



Julius Karl D. Fieve 
AUTHOR



Julius Karl D. Fieve is an innovative International Development Specialist with over 8 years' experience in non-profit, private, and public sectors. He holds MSc. Africa and International Development from the University of Edinburgh, UK as a Mastercard Foundation Scholar. He also holds MSc. Economics and a BSc. Actuarial Science, all from the Kwame Nkrumah University of Science and Technology (KNUST), Ghana. He equally holds an Executive Certificate in Project Management from the African Centre for Capacity Building (AFCAB), Accra, Ghana. He was a Research Fellow at the West Africa Civil Society Institute (WACSI) in 2020.

\section{Editorial Team}

Jimm Chick Fomunjong - Head, Knowledge Management Unit, WACSI

Nancy Kankam Kusi - Programme Officer, Knowledge Management Unit, WACSI

\section{About WACSI}

The West Africa Civil Society Institute (WACSI) was created by the Open Society Initiative for West Africa (OSIWA) to reinforce the institutional and operational capacities of civil society in the region. WACSI also serves as a resource centre for training, research and documentation, experience sharing and political dialogue for CSOs in West Africa.

www.wacsi.org

\section{About WACSeries}

WACSeries are analytical periodic write-ups on topical themes and issues relevant to West Africa. These write-ups provide experts, researchers and practitioners a space to reflect, analyse and posit views and recommendations on emerging issues and debates. The WACSeries Issue Paper are thought provoking and intellectually engaging write ups that provide critical reflections and analysis of issues relevant to civil society and development in West Africa.

\section{Obectives of WACSeries}

- To raise awareness on key issues in West Africa;

- To generate debates and discussions on these issues;

- To proffer recommendations on civil society involvement in advocacy;

- To provide recommendations to policy makers. 




\title{
Assessing the Influence of the Media on the Work of Development Organisations
}

\author{
A Case Study Evidence of the Comprehensive Sexuality Education (CSE) Policy \\ and the Female Genital Mutilation (FGM) Practice in Ghana
}

\section{Copyright WACSI 2021}

All rights reserved. No part of this report may be used or reproduced in any manner whatsoever without written permission of the Institute except in the case of brief quotations embodied in critical articles and reviews. For more information write to:

West Africa Civil Society Institute (WACSI)

No. 9 Bamboo Street, East Legon

P.O. Box AT 1956, Achimota

Accra, Ghana

Email : research@wacsi.org

Tel : +233 (0) 302550224

Cite this document as: Fieve, J., K., D. (2021). Assessing the Influence of the Media on the Work of Development Organisations, WACSeries, Issue Paper, Vol. 7, Issue 6, West Africa Civil Society Institute, Accra, Ghana.

Disclaimer: The views expressed in this article are solely those of the author. WACSI does not take responsibility for the views expressed. 


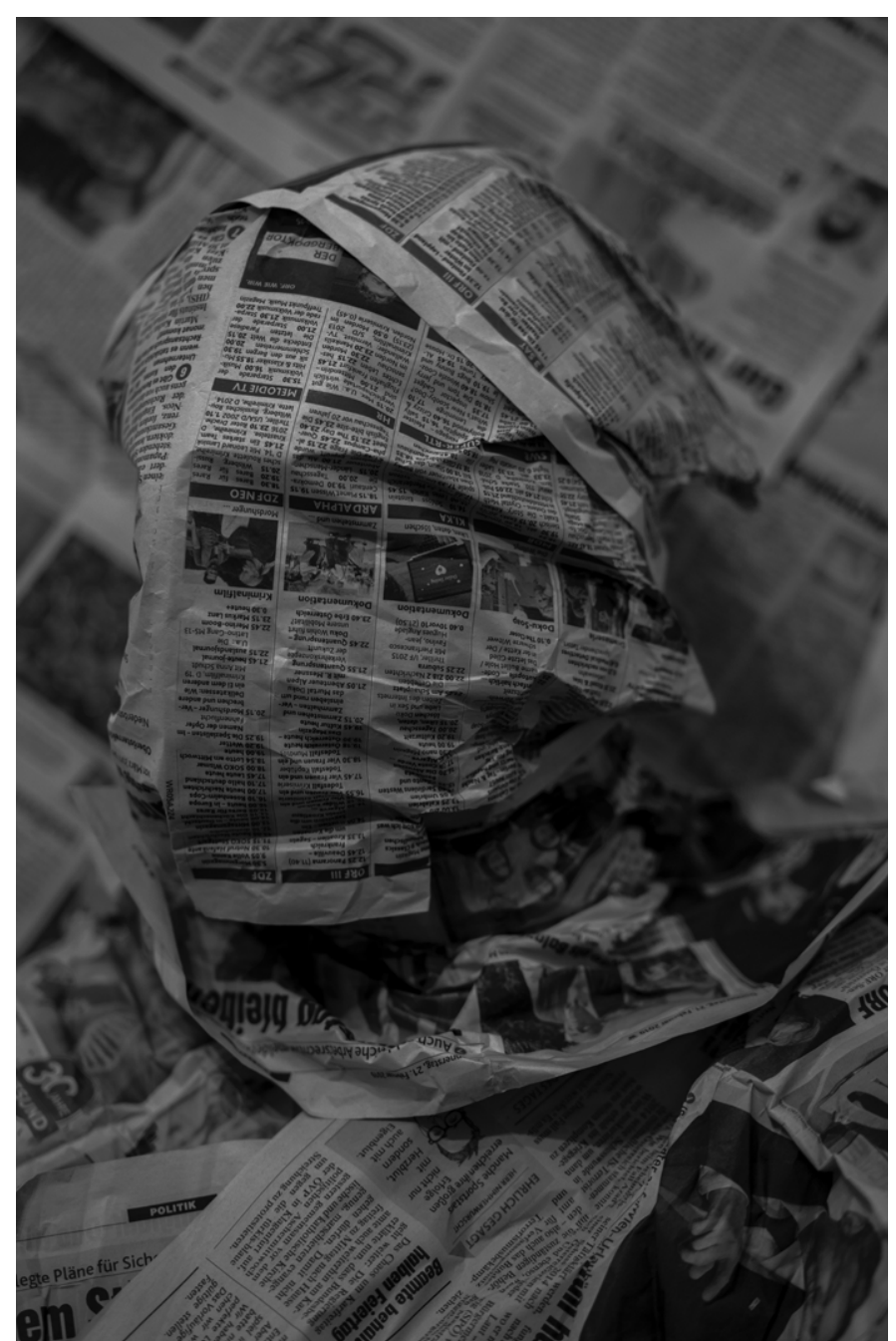

Photo by Teslariu Mihai on Unsplash

\section{Abstract}

This paper assesses the influence of the media on the work of development organisations. It employed case study evidence of the comprehensive sexuality education (CSE) policy and the female genital mutilation (FGM) practice in Ghana. The paper argues that the media does not only impact the works of development organisations but influence their identity, how they are perceived and rated by the public, governments and donors which determines their ability to raise funds and achieve the objectives of their development interventions.

The paper equally establishes that development organisations also influence the effectiveness of the media in discharging their duties. The paper calls for close partnership between the media and development organisations in sustaining and advancing their works.

\section{Introduction}

The media has become a great partner influencing the development focus of organisations, governments, and other institutions. It has served as a watchdog and gatekeeper constantly shaping public opinion, creating awareness, promoting good governance and development by documenting and reporting on socioeconomic developments such as issues of public health, education, women empowerment among others (Sikanku, 2011). Its reporting practices, priorities and community-level interventions determine how humanitarian activities, emergencies, structural disadvantages, and global poverty are covered in news, structured, sensationalised, or simply buried (Porche, 2004; Ecker-Ehrhardt, 2010). Their publications generally determine how works and interventions of development organisations are viewed and rated by the public. Development organisations have, in numerous instances influenced the work of the media. They have equally been part of the success story of the media especially in Africa and other developing countries since the 1990s.

This paper uses the role of the Ghanaian media in cancelling the comprehensive sexuality education (CSE) policy in Ghana and criminalising the practice of female genital mutilation (FGM) to analyse the interdependence and reciprocal influence between media and development organisations.

Ghana was selected for this study because the media has been progressively vibrant and has strongly asserted itself in shaping policy discourse in the country. The media landscape to an extent enjoys press freedom devoid of interferences from government and nongovernmental organisations, hence an appropriate avenue for discussions on the media's roles. Due to the sensitivity of the topics, most media personnel spoke on conditions of anonymity. The media as used by this paper refers to all channels of print, broadcast and electronic communication be it traditional or social that are used to inform, educate, and influence the thinking and behaviour of the public (Sikanku, 2011). Development organisations refers to local, national, regional, international, and multilateral organisations that undertake development works and humanitarian activities independent of their host countries. They could be civil society organisations (CSOs), non-government organisations (NGOs) or multilateral organisations. 


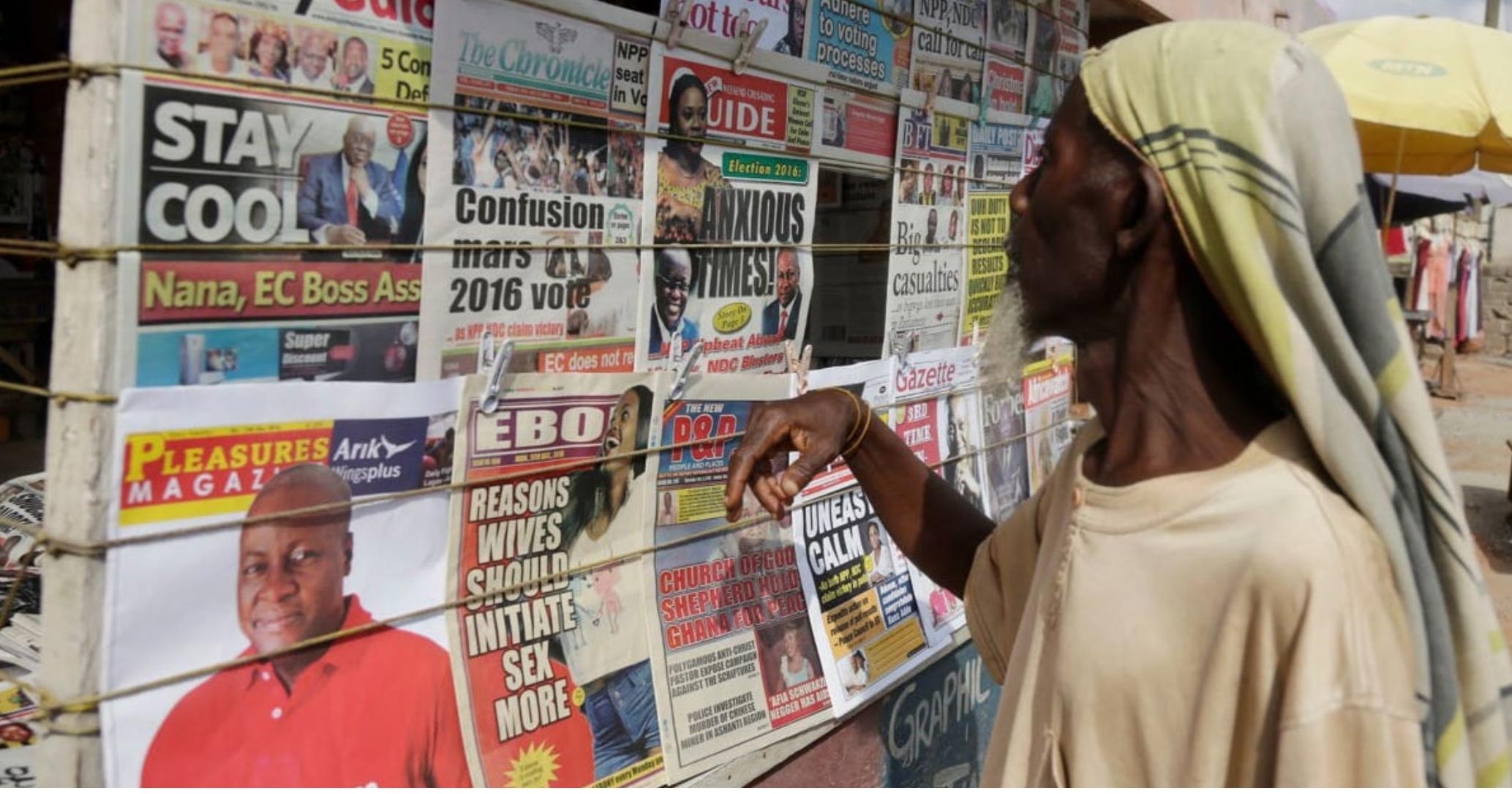

Photo from https://ifex.org/

Scholarly discussions around the role of the media in development works have been centred around the media giants in the global north to the neglect of those in the global south especially Africa. Western literature and scholarly articles consider Al Jazeera, BBC, CNN, the Guardian, and other western media as being set up with the specific and articulated goals of giving "voice to the voiceless" and telling stories from the perspective of the underprivileged (Figenschou 2010: 86). But little is written about the works of the Daily Graphic, Multimedia, and the Ghanaian Chronicle in Ghana, the All Nations in Kenya, the Vanguard in Nigeria among others in the global south. Meanwhile many of these media in the global south have also been strongly on guard reporting on issues of local, national, and international interest to influence the works of development of organisations (Mawdsley, 2017). This paper, on this note, builds its argument on the role of the media in Ghana in influencing the work of development organisations

\subsection{The Influence of Media on Development Organisations}

Across the globe, the media is noted for raising awareness on issues of national and global development among their constituents. They serve as a panacea to development barriers and obvious vehicle for social change and a tool for sustainable development (Omotoso, 2010). They achieve this by engaging in a wide range of programmes on topical issues such as education, poverty reduction among others to influences the attitude, awareness, and behaviour among the populace (Kafewo, 2014).
The media does not only impact the works of development organisations but influences their identity, how they are perceived and rated by the public, governments and donors which determines their ability to raise funds for development interventions.

Save the Children, a UK non-governmental organisation (NGO) was an example. The Organisation came under incessant media scrutiny in the periods of 2012 to 2018 for its failure to investigate and punish some former directors over staff allegations of sexual harassments. This prompted the Charity Commission to launch a full investigation into the allegations in 2015 (Guardian, 2018). The fund-raising ability of the organisation was negatively impacted and in turn affected their development interventions during the period. For instance, the income statement published by the organisation in December 2018 showed a $£ 104$ million drop in their income from $£ 407$ million to $£ 303$ million and a loss of over 7000 public donors. Some of their directors also resigned during the process (Save the Children, 2018).

In another instance, an excessive allegation of embezzlement of EUR 1.2 million levelled against the International Helsinki Federation for Human Rights by the Australian media saw its closure for insolvency in 2007 and imprisonment of its former finance manager in 2008 (Trivunovic, 2011). A significant strategy of development organisations is to use celebrities (ambassadors) to promote their brand and development works. However, media publications about a particular development organisation determines its public trust and credibility 
which are bankable currency to woo celebrities and donors (Nolan and Cottle, 2009). For instance, the Red Cross lost most of their ambassadors and funding streams when media reports showed Medecins Sans Frontieres (MSF) accusing them of mishandling public donations following the Bali Bombing in 2004. The media claims and counterclaims by Red Cross and MSF caused massive damage to the public image of both organisations making them lose their ambassadors in the process (Nolan and Cottle, 2009). These instances proof that people and donors want to support the development efforts of $\mathrm{NGOs,} \mathrm{but} \mathrm{they} \mathrm{want} \mathrm{organisations} \mathrm{that} \mathrm{are} \mathrm{transparent,}$ responsive, credible, and accountable (Omotoso, 2010).

The role of the media also determines how effective NGOs are in advocacy and campaigns especially against practices that are discriminatory and inhumane but shrouded in the culture and tradition of local communities. For instance, it was the campaign by the media in Ghana that supported International Needs Ghana (ING), an NGO in pressuring the Ghanaian government to abolish the trokosi (slave girl) practice in 1997 which had been in existence for over 300 years (Akyeampong 2001). By this practice virgin girls aged 6 and above were captured to serve a shrine and become sexual partners to fetish priests, sometimes for periods lasting a lifetime in atonement for sins committed by their family members. Over 5000 girls had fallen victim to this practice since 1600 until it was placed under media spotlight in the 1990s and had ING championing for its abolishment and criminalisation in 1997 (Gedzi, 2016).

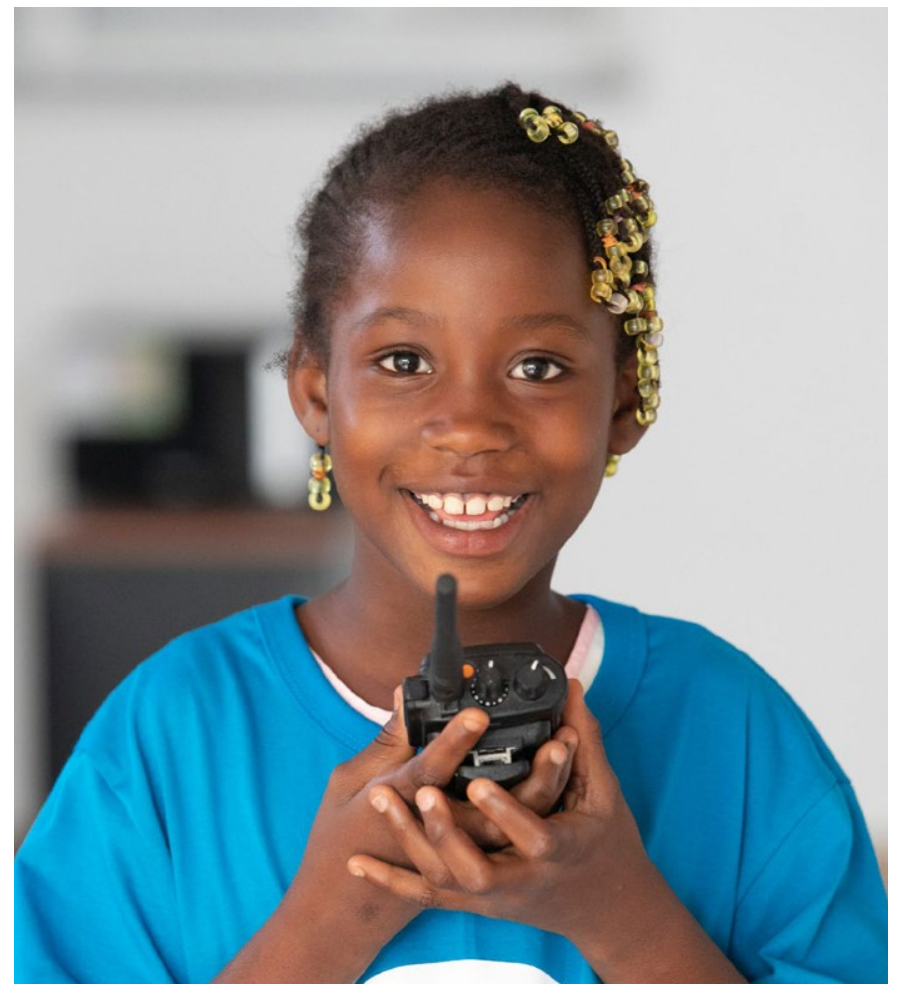

Photo from https://www.everywomaneverychild.org/
These instances clearly show that the media produces and distributes contents which influences the works of development organisations, how they raise funds, increase, and strengthen access and flow of information to the public for decision making by stakeholders.

\subsection{The Role of the Media in Fighting the Comprehensive Sexuality Education Policy}

The media in Ghana has been active in fostering debates around inherently contentious social, economic, cultural, and political issues to shape public opinion against some interventions of development organisations (Beckett and Kyrke-Smith, 2007). One such instance was the campaign by the media against the introduction of the comprehensive sexuality education (CSE) into the educational curriculum of basic and secondary schools in Ghana in 2019. The CSE was developed by the United Nations Population Fund (UNFPA) and the Government of Ghana (GoG) with funding from the United Nations Education, Scientific and Cultural Organisation (UNESCO). The UNFPA defines the CSE as a curriculum-based education that aims to equip children and young people with the knowledge, skills, attitudes, and values that will enable them to develop a positive view of their sexuality, in the context of their emotional and social development (UNFPA, 2014).

The organisation believes that by embracing a holistic vision of sexuality and sexual behaviour, adolescents can achieve their full potential, become gender sensitive and realise their sexual and reproductive health and rights. UNFPA hoped to introduce the CSE concept into the educational curriculum of Ghana and 14 other countries in 2019. This followed its successful introduction in Scotland where it was mainstreamed into the health and well-being policies supported by the Children and Young People (Scotland) Act 2014 (O'Neil, 2017). This equally followed its introduction in some East and Southern African (ESA) countries such as Malawi, Botswana, Lesotho, Kenya, Malawi, Namibia, South Africa, Swaziland, Uganda, Zambia, and Zimbabwe after a review of the school curriculum in those countries (UNFPA, 2012).

In line with that the UNFPA and Government of Ghana (GOG) issued a guideline in 2018 on CSE in schools. The idea was to officially incorporate the CSE into educational curriculum of schools from creche to the secondary school levels as well as enable teachers to deliver these programmes with confidence and empathy (GES, 2018). 
In preparations, GOG and UNFPA engaged religious leaders and key stakeholders on the issues of sexual and reproductive health at a national summit in 2018. They also reached out to the media to communicate the guideline to the wider public and urge journalists to provide more responsible coverage of issues related to adolescent girls. Over 152,000 teachers were also trained to kick start the new curriculum and the programme was to start in October 2019 (Ghanaweb, 2019a). Around September 2019, the local media investigated the training manual of teachers on the CSE prepared by UNFPA and GOG.

The media alleged to have found elements that contradicts the cultural norms and traditional values of the Ghanaian society. They therefore decided to foster debate around it through their editorials, panel discussions, news reporting, opinion pieces, community level engagements, expert analysis, and writings on all their radio, TV, newspaper, and social media platforms. They cited similar resistance against the introduction of CSE in Mexico (ChandraMouli et al, 2018) and some other Africa countries such as Kenya and Zambia. Below are few reactions from some journalists who participated in the media campaign at the time:

"So, some critics drew our attention to discrepancies in the CSE curriculum. We saw it as a mean to indoctrinate the children in Ghana into what we consider an adult content. This we believe will lead the children into learning and further practicing sexuality at the age not expected of them. We also see it as an angle of LGBTQ which the Ghanaian society abhors due to our culture and Christian values" (A journalist in a leading media house in Accra, Ghana)".

"People kicked against it because we think a lot of the principles that were being espoused in the syllabus do not reflect our cultural norms as a people. Content like children should be taught how to touch themselves if they are afraid of engaging with people of opposite sex cannot be encouraged in our society. Such detailed issues of sex should be left to mothers and fathers, so they decide what to teach their children. Not for teachers and schools. That would amount to teachers and schools overreaching their mandate. That's why people kicked against it" (Another senior journalist in Accra, Ghana)".
As a result of the media's intervention, family campaigners, religious leaders and groups and ordinary Ghanaians raised an outcry and a nationwide protest using the media to accuse the UNFPA and GoG of deliberately introducing Lesbian, Gay, Bisexual and Transgender (LGBT) agenda into the Ghanaian society. They described the introduction of the CSE as a form of neo-colonial and imperialist agenda to introduce un-African, "satanic" and pro-LGBT agenda in the society (Ghanaweb, 2019b). They echoed the argument that Africans see same-sex relations as foreign and un-African (Baisley, 2015). Moses Foh Amoaning, Lawyer and leader of the National Coalition for Proper Human Sexual Rights and Family Values, a pressure group claimed homosexuality is a sin. Some critics in a statement below also cited a similar media war in 2006 which culminated in the government cancelling a purported LGBT conference scheduled to happen in Ghana at the time (BBC, 2006).

"I call it comprehensive satanic engagement," said Paul Yaw Frimpong-Manso, president of the Ghana Pentecostal and Charismatic Council, on local radio station Joy FM.

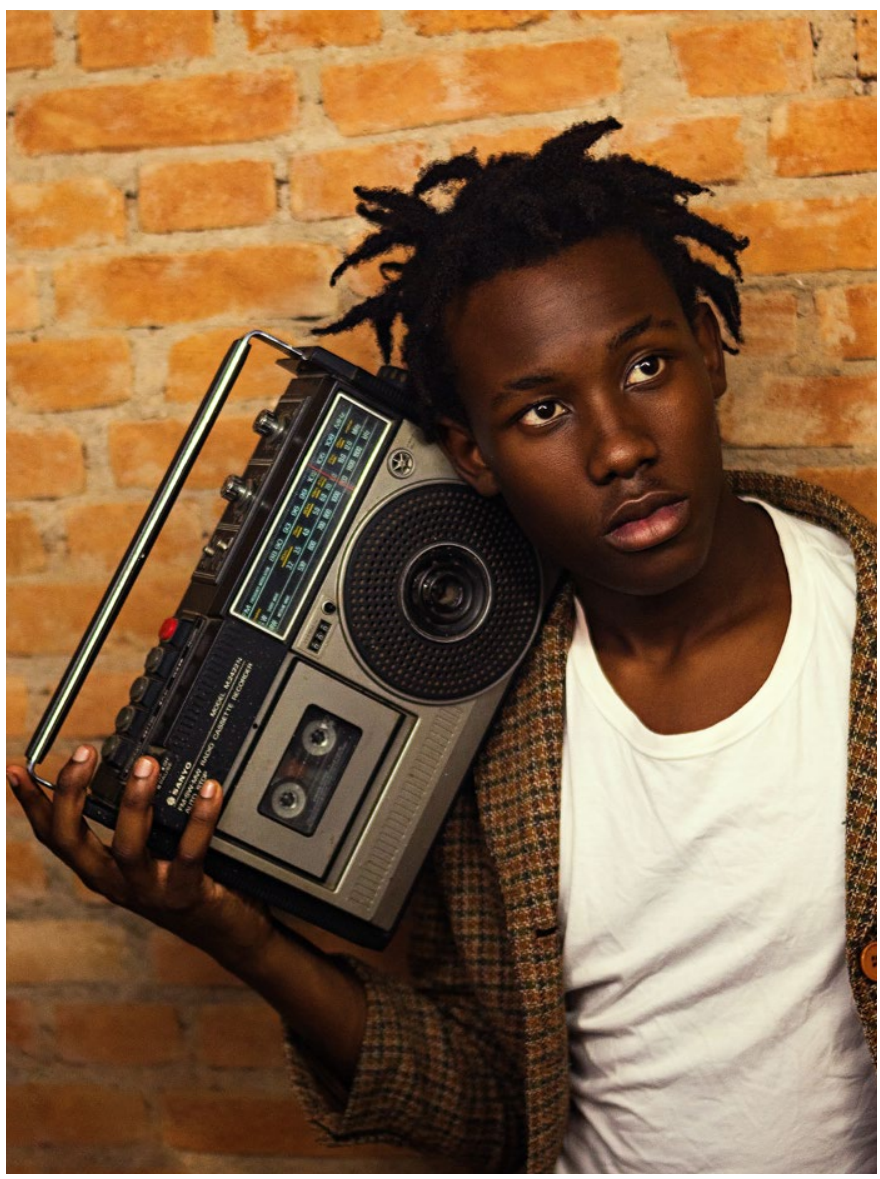

Photo by Vine Alexandre from Pexels 


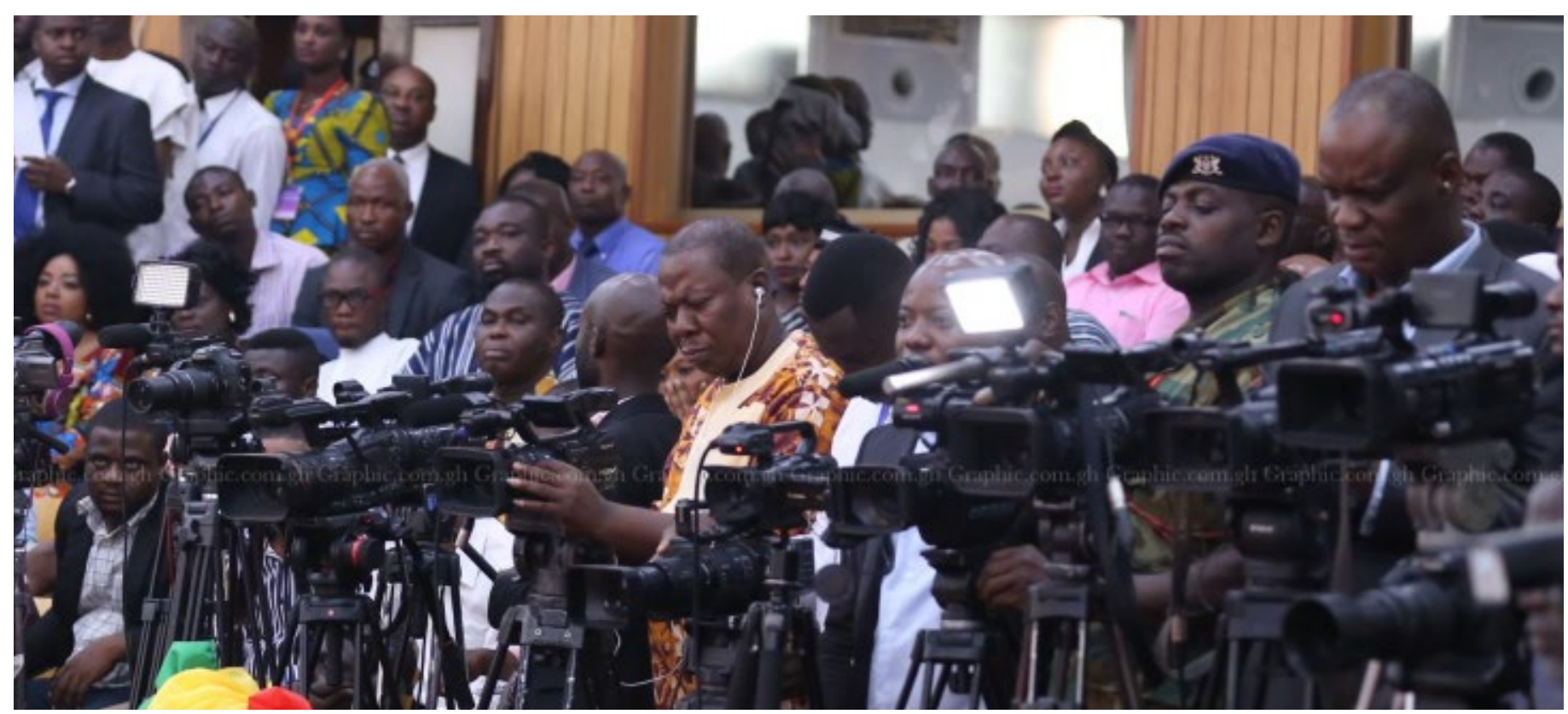

Photo by Graphic Comms via https://www.mfwa.org/

\begin{abstract}
"We were just making the voices of stakeholders heard. I understand that there were prior consultations with stakeholders and a review has been carried out pending acceptance by the Ghana Education Service (GES). For the review, the module has been localised putting into consideration, our culture religious values and the like. They kicked against it because other versions of the module meant for other countries has been making the rounds, instead of the one modified for use in Ghana. They particularly had issues with the "sexuality" aspect, which is illegal in Ghana. So, it was a complete mix up" (a senior journalist in Accra).
\end{abstract}

The government and UNFPA quickly came in to dispute the allegations and calmed the public down. As quoted by Ghanaweb, (2019), the Minister of Education assured the public that "the government and the ministry will not compromise societal values in the delivery of quality education". The President of the Republic of Ghana engaged several stakeholders and segments of society over the issue. Some media practitioners however believe that governments and UNFPA's engagements with stakeholders were inadequate hence the opposition against the CSE curriculum.

"Government's inability to properly sit down with stakeholders to agree on how to go about the introduction of the policy made it a failure from the very beginning. We carried the views of the people who said they don't want it." (Another senior journalist in Accra, Ghana).
Despite these engagements by the government and UNFPA, the media joined by opposition parties and the public intensified their call for the withdrawal of the policy and the new curriculum that was alleged to have been printed and ready to be introduced. Even though the government and UNFPA believe the media and critics were misinforming the public, they heeded to the pressure and withdrew the CSE in October 2019 (Ghanaweb, 2019c). Government and UNFPA however considered the discontinuation of the process to introduce the CSE as a big setback of their agenda of making children aware of their sexual and reproductive rights. The media rather see their involvement in amplifying the voice of the critics of CSE as a way of protecting the cultural and national identity of Ghana and promoting social development. This clearly shows that media involvements in development could cause paralysis in decision making and implementation, limit the powers of authorities and extend media influence (Kuu-Ire, 2009).

\subsection{The Role of the Media in the Criminalisation of Female Genital Mutilation Practice}

It must be established that the media in Ghana is not always in disagreement with development organisations. It plays that essential role in delivering the information people need to participate in debates and decisions that shape their lives and development (Becket and KyrkeSmith, 2007). Hence, it has in so many instances supported development organisations and government to inform and empower the general populace and shape their opinions towards a particular development path. One of 




Image by Pashminu Mansukhani from Pixabay

such instances was the campaign in support of the World Health Organisation (WHO) and the GoG to criminalise the practice of female genital mutilation (FGM). FGM as defined denotes any procedure involving partial or total removal of the external female genitalia, as well as injury to the female genital organs for non-medical reasons (WHO, 2008). More than 200 million girls and women alive have undergone FGM primarily in some 30 countries in Africa (WHO,2020).

It is obvious that the practice of FGM is not only a severe form of discrimination against women but also a violation of the rights of girls on whom it is/was performed (Kaunga, 2014; WHO, 2008). As reported by WHO, UNICEF and UNFPA, among others these women and girls living with FGM faces complications such as infections and psychological trauma. They are also more likely to face mental health disorders or suffer life-long chronic infections, experience life-threatening complications during childbirth and have pain or problems when they menstruate, urinate, or have sexual intercourse (WHO, 2020). Economically, it was revealed through a new cost modelling concept that the total cost of treating the health impacts of FGM amounts to $\$ 1.4$ billion per annum globally if all resulting medical needs were addressed
(WHO, 2020). The report further said this cost could near $10-30 \%$ cost of the entire annual expenditure on health coverage in some countries.

Even though the practice of FGM was in existence for years, it was not until the 1990s when the media across Africa started to turn attention to FGM reporting (ShellDuncan and Hernlund, 2000). Ghanaian media houses such as the Chronicle, the Observer, the Daily Graphic among others consider FGM inhumane and barbaric. A female Journalist in Ghana has this to say:

"FGM is barbaric, primitive and it's continuous practice in some cultures is not only a disregard for human 'life', but a gender-based violence and sexist act. FGM is traumatic and inflicts physical and psychological scars on its victims to last a lifetime. $F G M$, has been outlawed in several countries though some people in countries which are signatories to laws banning FGM still engage in the practice" ( $A$ female journalist in Ghana).

The media across the country therefore launched an intense media campaign through their editorials, news reportages (coverages), commentaries, documentaries, interviews, and announcements against FGM resulting in the criminalisation of the practice in 1994 (Thomson Reuters Foundation, 2008; Erturk, 2015). As a result of the criminalisation and intense media scrutiny, two culprits were successfully prosecuted and imprisoned in 2003 and 2004 to five-year jail terms for circumcising three girls with the consent of their parents (Aberese and Akweongo, 2018).

Despite the criminalisation and the subsequent prosecution and imprisonment of those culprits in 2003 and 2004, the media in Ghana continue to report on FGM and the need to totally eradicate it. They reported FGM as a problem in $100 \%$ of their articles on the topic. The Chronicle: a Ghanaian newspaper outlet with readership of over 250,000 people was particularly recognised as one of the fierce critics of FGM in Ghana and Africa (Sobel, 2015). The Daily Graphic for instance reported with marketable headlines such as "more women abhor female genital mutilation", "female genital mutilation denies women, girls their dignity" and "Sudan criminalises female genital mutilation (FGM)" to inform their readers about the negative impact of the practice on their victims (Daily Graphic, 2013;2017; 2019; 2020). The Ghanaian Chronicle titled the stories on female genital mutilation as 
"how do we end female genital mutilation" and "female circumcision still going on" (Ghanaian Chronicle, 2001; 2005). The Chronicle in one of their publications on FGM in 2001 sensationalised portions such as '...the girls escaped and sought refuge in a local Presbyterian church", the story said, "but their parents, determined to enforce the ritual, organised a mob, stormed the church and dragged the poor girls out to face the traumatic experience of female circumcision" (Ghanaian Chronicle, 2001; Sober, 2015). This was obviously an attempt to problematise the FGM practices. A journalist interviewed in Accra; Ghana who spoke on the condition of anonymity has this to say about FGM practices.

\section{"It causes health complications and infections putting the girls in real danger"}

The increased media coverage made parliament to further strengthen the anti-FGM law in 2007 by increasing the maximum penalty to 10 years of imprisonment and extending the range of persons who can be prosecuted for involvement in the act to include parents of the victims (Thomson Reuters Foundation, 2008).

Some cultural practitioners and traditional leaders however accused the media and anti-FGM campaigners of sensationalising and reproducing a neo-colonialist and imperialist narrative to promote western superiority and punish vulnerable populations instead of protecting them (Nnaemeka, 2005). Some argued that such laws are not really about women's well-being, but merely a way for development organisations to 'pretend to address race and gender issues' (Gunning, 1999: 51). They believe FGM is a cultural ritual and necessary component in preparing girls for adulthood and marriage (WHO, 2008). This is fuelled by a local African belief about femininity and modesty, which is grounded on the belief that girls are "clean" and "beautiful" after the removal of body parts that are considered "male" and "unclean" (Aberese and Akweongo, 2018).

The WHO was very appreciative of the media for their role which led to the criminalisation of FGM in Africa, the Middle East and some 33 other countries with migrant populations from FGM-practicing countries. The organisation believes that the media shaped the views of the public and national governments which led to the criminalisation of the practice in most countries including Ghana (WHO, 2020).



Photo by Wherda Arsianto on Unsplash

\subsection{The Influence of Development Organisations on the Media}

It must however be noted that it is not only the media that influences the works of development organisations. These development organisations also influence how the media is funded and how easily they get access to information. For instance, Thomson Reuters Foundation (TRF) has since 1983 built capacity for free trusted and independent media. They have so far trained over 18,000 journalists and media personnel from countries such as Ghana, Nigeria, Cameroon, Senegal, Kenya and 170 other countries across the world. The Foundation also recently trained some selected West African journalists in Lagos, Nigeria on slavery and trafficking in December 2019 (TRF, 2020).

Development organisations sometimes determine how the media is funded and how easily they get access to information and capacity development opportunities. The Friedrich Ebert Stiftung (FES); the Danish International Development Agency (DANIDA); and the US Agency for International Development (USAID) for instance have also been involved in media development activities in Ghana over the years (Kafewo, 2014). Some foreign embassies 


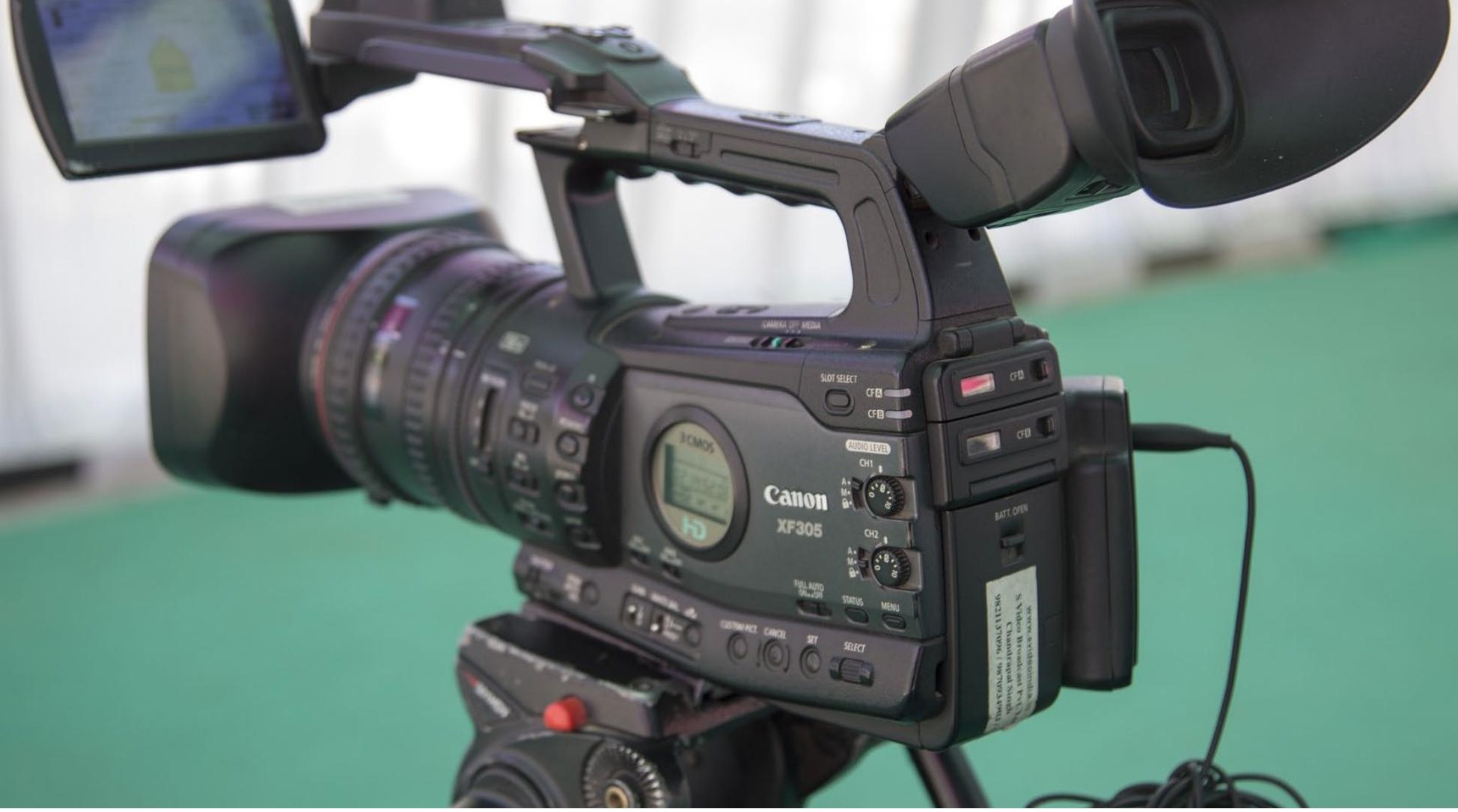

Image by fernandoprado from Pixabay

such as the Dutch Embassy, US Embassy and British High Commission also provide aid of various kind to the media in Ghana. For instance, USAID has since the last decade been supporting the Media Foundation for West Africa (MFWA) and Ghana Journalist Association in planning and organising the West Africa Media Excellence Conference and Awards on annual basis (US Embassy, 2019). The organisation has used the conference as a platform to promote and protect a free press which is an essential pillar of democracy.

Other key local NGOs who also serve as umbrella bodies for journalist (media practitioners) and involved in media development such as Centre for Media Analysis, Journalists for Human Rights (JHR); and, the Media Foundation for West Africa (MFWA) have been active in promoting media development in Ghana and the West African Sub Region. They do these with funding and logistics support from international development organisations all over the world. These organisations usually train media practitioners across Ghana and the West Africa sub region in issues of ethics, laws governing their profession, electoral reporting, HIV/AIDS reporting, human rights and development, online journalism, coverage of legislative and environmental matters among others (Kafewo, 2014). For example, the MFWA in partnership with SocioserveGhana organised special training on conflict-sensitive reporting for 20 journalists from five regions across Ghana in 2016 (Media Foundation for West Africa, 2016).

\section{Conclusion}

This paper has described the media as a watchdog and gatekeeper influencing development organisations in implementing and discharging their institutional responsibilities to promote human development and deal with socio-economic challenges facing the world (Wallack, 1981). The implementation of the FGM and the failure of the CSE programme was the public agenda amplified by the media in Ghana.

Through the framing of the problem, in-turn, transforming it into a story, the media can dictate how policy makers and the public understand social, economic, and political problems and, subsequently, respond to it (Harp et al., 2010; Sobel, 2015). The paper is however not arguing that the media has single handily colonised the invaluable work development organisations undertake in the field or even on the home front. The paper believes there is more to development works that to the idealisation and media image of development organisations (Cottle and Nola, 2009). 


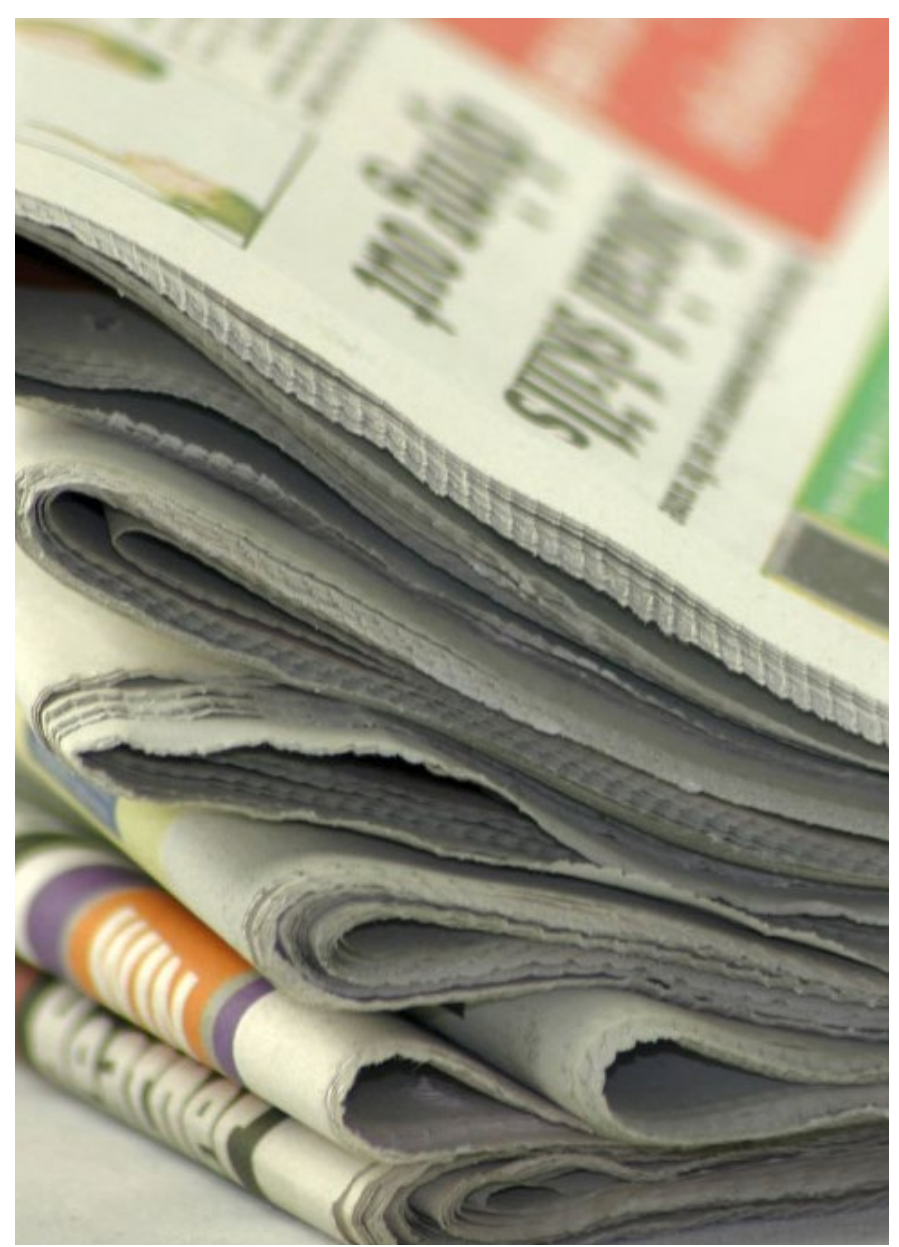

Photo by Buzz Ghana via https://www.pambazuka.org/

\section{Recommendations}

This paper recommends that to sustain their works, development organisations need to:

- Develop effective media strategies and build capacity of local journalists to report on developmental issues. These capacity development initiatives could be developed together by the development organisations and the media.

- Forge and maintain positive relationships with media organisations not only to cover their development works but to also update them on different issues and research findings.

- Mainstream healthy media agenda into their projects and programmes and develop a framework for sustainable media collaborations.
This can be designed through the taking critical perspectives on development journalism, monitoring and evaluation of standard and quality of development news and reports, and practical recommendations for media collaborations in the future.

- Foster responsible media interaction and increased trust among themselves and the media at all levels of society.

- Mainstream media development efforts into their interventions to improve media literacy targeted not only at journalists but all persons within the media space.

\section{The paper also calls on the media to:}

- Seek accurate information from development organisations before reporting and publishing to the public.

- Build a healthy and unbiased partnership and synergy with development organisations to expose challenges facing humanity.

- Work with development organization to get access to specialized training opportunity, funding streams and deep geographical expertise.

- Continue supporting development organisations engaged in positive developmental interventions to get the recognition and influence from their donors and supporters. 


\section{SOURCES AND BIBLIOGRAPHY}

Aberese Ako, M. and Akweongo, P., 2009. The limited effectiveness of legislation against female genital mutilation and the role of community beliefs in Upper East Region, Ghana. Reproductive Health Matters, 17(34), pp.47-54.

Akyeampong, E., 2001. History, memory, slave-trade and slavery in Anlo (Ghana). Slavery and Abolition, 22(3), pp.1-24.

Baisley, E., 2015. Framing the Ghanaian LGBT rights debate: Competing decolonisation and human rights frames. Canadian Journal of African Studies/Revue canadienne des études africaines, 49(2), pp.383-402.

Beckett, C. and Kyrke-Smith, L., 2007. Development, Governance and the media: The role of the media in Building African Society.

Boyle, E.H., 2005. Female genital cutting: Cultural conflict in the global community. JHU Press.

British Broadcasting Corporation (BBC), 2019, Gay Conference Banned. Accessed: 30th May 2020: http://news.bbc.co.uk/1/hi/ world/africa/5305658.stm

British Broadcasting Corporation (BBC), 2019, Ghana/UNESCO Comprehensive Sexual Education: Parents bore plan wey authorities wan introduce to kiddies. Accessed: 30th May 2020: https://www.bbc.com/pidgin/tori-49875450

Bunce, M., Franks, S. and Paterson, C., 2016. Introduction: A new Africa's Media Image?. In Africa's Media Image in the 21st Century (pp. 19-32). Routledge.

Chandra-Mouli, V., Garbero, L.G., Plesons, M., Lang, I. and Vargas, E.C., 2018. Evolution and resistance to sexuality education in Mexico. Global Health: Science and Practice, 6(1), pp.137-149.

Daily Graphic, 2013., More women abhor female genital mutilation. Accessed: 20th June 2020 https://www.graphic. com.gh/news/health/more-women-abhor-female-genitalmutilation.html

Daily Graphic, 2019., Female Genital Mutilation denies women girls their dignity. Accessed: 20th June 2020. https:// www.graphic.com.gh/news/general-news/female-genitalmutilation-denies-women-girls-their-dignity.html

Daily Graphic, 2019., Victim of FGM suffer lifelong consequencesUN Women. Accessed on 20th June 2020 https://www.graphic. com.gh/news/general-news/ghananews-victims-of-fgmsuffer-life-long-consequences-un-women.html

Daily Graphic, 2020., Sudan criminals female genital mutilationfgm. Accessed on 20th June 2020 https://www.graphic.com. gh/international/africa/sudan-criminalises-female-genitalmutilation-fgm.html

Dorkenoo, E., 1994. Cutting the rose: female genital mutilation: the practice and its prevention.
Ecker-Ehrhardt, M., 2010. Aid organisations, governments and the media: The critical role of journalists in signaling authority recognition. In Public Policy and the Mass Media (pp. 124-142). Routledge.

Figenschou, T.U., 2010. A voice for the voiceless? A quantitative content analysis of Al-Jazeera English's flagship news. Global Media and Communication, 6(1), pp.85-107.

Gbolu F and Jacques J (2005) Female circumcision still going on. Ghanaian Chronicle, 6 July.

Gedzi, V.S., 2016. Field Of Power: A Religio-Cultural Analysis Of Trokosi In Ghana. Political Science, 1, pp.122-142.

GeoPoll, 2018, Ghana Media Measurement. Accessed on 30th May 2020. https://www.geopoll.com/blog/ghana-mediameasurement-top-tv-radio-2018/

Ghana Education Service. 2018. Guidelines for Comprehensive sexuality education (CSE) in Ghana. Accra, Government of Ghana.

Ghanaweb, 2019a. CSE not part of curriculum Napo. Retrieved https://www.ghanaweb.com/GhanaHomePage/NewsArchive/ CSE-not-part-of-curriculum-Napo-785387 . Accessed: 26th March 2020

Ghanaweb, 2019b, Ghanaians fight satanic sexuality education programme. Retrieved from: https://www.ghanaweb.com/ GhanaHomePage/NewsArchive/Ghanaians-fight-satanicsexuality-education-programme-785459 - Accessed: 29th March 2020

Ghanaweb, 2019c, Akuffo Addo withdraws CSE. Retrieved from https://www.ghanaweb.com/GhanaHomePage/NewsArchive/ Shameful-Akufo-Addo-succumbs-to-pressure-withdraws-CSEBrogya-Genfi-reveals-786928. Accessed on 29th March 2020.

Ghanaian Chronicle (2001) How do we end female genital mutilation? Ghanaian Chronicle 13 November.

Guardian (2018). Save the children inquiry. Retrieved from: https://www.theguardian.com/society/2018/apr/11/save-thechildren-inquiry-staff-misconduct-brendan-cox . Accessed 27th March 2020

Gunning, I.R., 1999. Global feminism at the local level: Criminal and asylum laws regarding female genital surgeries. J. Gender Race \& Just., 3, p.45.

Harp, D., Loke, J. and Bachmann, I., 2010. Voices of dissent in the Iraq war: Moving from deviance to legitimacy?. Journalism \& Mass Communication Quarterly, 87(3-4), pp.467-483.

James, S.M. and Robertson, C.C. eds., 2002. Genital cutting and transnational sisterhood: Disputing US polemics. University of Illinois Press 
Kafewo S., 2014, Research findings and Conclusions, African Media Development Initiative, Ghana.

Kalyango Jr, Y. and Adu-Kumi, B., 2015. Impact of social media on political mobilization in East and West Africa. Global Media Journal, 2013.

Kassindja, F. and Bashir, L.M., 1999. Do they hear you when you cry. Random House Digital, Inc..

Kaunga, S., 2014. Media strategies and their influence in communicating information on Female Genital Mutilation: a case of Meru community in Tharaka District (Doctoral dissertation, University of Narobi).

Kuu-Ire, S.M., 2009. The mass media profession in Ghanaian national development: a development partner or scourge?. Ghana Journal of Development Studies, 6(2).

Media Foundation for West Africa (MFWA), 2020. Socioserve Ghana train journalist on conflict sensitive reporting. Accessed on: 20th June 2020. https://www.mfwa.org/country-highlights/ mfwa-socioserve-ghana-train-journalists-on-conflictsensitive-reporting/

Mawdsley, E., 2017. Development geography 1: Cooperation, competition and convergence between 'North'and 'South'. Progress in Human Geography, 41(1), pp.108-117.

Myers, M., 2014. Africa's media boom: The role of international aid. CIMA, National Endowment for Democracy.

Nnaemeka, O. ed., 2005. Female circumcision and the politics of knowledge: African women in imperialist discourses. Greenwood Publishing Group.

Nolan, D. and Cottle, S., 2009. How the media's codes and rules influence the ways NGOs work. Nieman Journalism Lab.

Omotoso, S.L., 2010. The use of media in community economic development practice: a case study of the Village Square, Nigeria (Doctoral dissertation, Southern New Hampshire University).

O'Neill, H. (ed.) (2017). Wellbeing in Our Schools: International Perspectives. CIDREE Yearbook 2017. Dublin: National Council for Curriculum and Assessment. http://www.cidree.org/wpcontent/uploads/2018/07/cidree yearbook 2017 wellbeing. pdf

Porche, D.J., 2004. Public and community health nursing practice: A population-based approach. Sage.

Population Council, 2012. Sexuality education: A ten country review of school curricula in East and Southern Africa.

Save the Children (2018), Annual Report. Retrieved from: https:// www.savethechildren.org.uk/content/dam/gb/reports/annualreport-2018-save-the-children.pdf . Accessed 27th March 2020
Shell-Duncan, B. and Hernlund, Y. eds., 2000. Female" circumcision" in Africa: culture, controversy, and change. Lynne Rienner Publishers.

Sikanku, E.G., 2011. Intermedia influences among Ghanaian online and print news media: Explicating salience transfer of media agendas. Journal of Black Studies, 42(8), pp.1320-1335.

Sobel, M., 2015. Female genital cutting in the news media: A content analysis. International Communication Gazette, 77(4), pp.384-405.

Thomson Reuters Foundation (TRF), 2020., Accessed on: ttps:// www.trust.org/journalism/

Trivunovic, M., 2011. Countering NGO corruption: Rethinking the conventional approaches. U4 Issue.

UNICEF, 2011. GHS. Multiple Indicator Cluster Survey (MICS), UNICEF, Accra, Ghana.

United Nations Population Fund and United Nations Population Fund, 2014. UNFPA operational guidance for comprehensive sexuality education (CSE): A focus on human rights and gender. Retrieved: https://www.unfpa.org/sites/default/files/pub pdf/ UNFPA $\% 20$ Pperational\%20Guidance $\% 20$ for $\% 20$ CSE $\% 20$ -Final\%20WEB\%20Version.pdf Accessed 27th March 2020,

Vanguard, 2019, Outrage in Ghana over introduction of sex education for children aged four. Accessed 30th May 2020: https://www.vanguardngr.com/2019/09/outrage-in-ghanaover-introduction-of-sex-education-for-children-aged-four/

US Embassy in Ghana, 2020., US support press freedom West Africa Media Excellence Conference Awards. Accessed on: 20th June 2020. https://gh.usembassy.gov/u-s-supports-pressfreedom-west-africa-media-excellence-conference-awards/

Wallack LM. Mass media campaigns: The odds against finding behavior change. Health Education Quarterly. 1981 Sep;8(3):209-60.

WHO (2008). Eliminating Female Genital Mutilation: An Interagency. UNAIDS, UNDP, UNECA, UNESCO, UNFPA, UNHCHR, UNHCR, UNICEF, UNIFEM, WHO,

Geneva.

World Health Organisation (WHO), 2020. Female Genital Mutilation hurst women and economies. Retrieved from: https://www.who.int/news-room/detail/06-02-2020-femalegenital-mutilation-hurts-women-and-economies . Accessed: 29th March 2020. 


\section{WACSI}

Strengthening Civil Society

(c) WACSI 2021 All Rights Reserved. 